\title{
Towards Developing a Common Conception of Research-Based Teaching and Learning in an Academic Community
}

\author{
Jaanika Blomster ${ }^{1}$, Stephen Venn ${ }^{1,2} \&$ Viivi Virtanen ${ }^{3}$ \\ ${ }^{1}$ Department of Environmental Sciences, University of Helsinki, Finland \\ ${ }^{2}$ Department of Biosciences, University of Helsinki, Finland \\ ${ }^{3}$ Faculty of Biological and Environmental Sciences, University of Helsinki, Finland \\ Correspondence: Jaanika Blomster, P.O. Box 65, 00014 University of Helsinki, Finland. Tel: 358-294-157-822. \\ E-mail: jaanika.blomster@helsinki.fi
}

Received: May 16, 2014 Accepted: June 26, 2014 Online Published: July 30, 2014

doi:10.5539/hes.v4n4p62 URL: http://dx.doi.org/10.5539/hes.v4n4p62

\begin{abstract}
This study aims to determine whether bioscience teachers and researchers in a research-intensive university have consistent views on research-based teaching, and to evaluate whether teachers' conceptions and views on practical teaching methods are aligned. Fifty-eight teachers completed a questionnaire concerning conceptions and practices of teaching. By using qualitative content analysis, we distinguished three categories of conceptions teacher-centred, student-centred and a view whereby pedagogical research was valued. Views on teaching practices were divided into five categories, according to how the teachers viewed students' involvement in research. A highly significant correlation indicated that teachers with more student-centred conceptions were likely to implement practices involving students in research and the academic community. Our study shows a plethora of conceptions of research-based teaching in an academic community and suggests that to enhance teaching quality in higher education, cooperation on the development of common conceptions is necessary; they will not evolve by themselves amongst academics.
\end{abstract}

Keywords: academic community, biosciences, higher education, research-based teaching, teachers' conceptions

\section{Introduction}

The three main tasks of universities are research, teaching and societal interaction. One of the main challenges in the every-day work of university teachers is often the pressure to promote science, whilst simultaneously carry out greatly varying amounts of teaching. Teaching is commonly perceived as a hindrance to research, and appreciation of the value of teaching tends to be low in comparison to that of generating research publications. In the model presented by Brew (2003), research is perceived to occur in a 'disciplinary research culture' and teaching in a 'departmental learning milieu', as a result of which teaching and research tend to pull in opposing directions, rather than complementing other. Research and teaching may even be perceived as incompatible, or as having little or no relationship with each other (Hattie \& Marsh, 1996; Robertson \& Bond, 2001). To shift from such antagonism towards a balance in which research and teaching are synergistic, a number of higher education researchers have called for a closer integration of research and teaching (Barnett, 1997; Brew, 2003; Hattie \& Marsh, 1996; Shore, Pinker, \& Bates, 1990).

There are contrasting views and traditions on the integration of research and teaching, depending on the academic communities and funding models in different countries. In countries where research and teaching are funded separately, such as the UK and Australia, there is a tendency to separate the two. This has led to the development of separate teaching institutions and research institutions, which is not congruent with the view that research and teaching are complementary. However, in many other countries, such as the USA, there is a strong link between research and teaching, and the two have been intentionally integrated (Brew, 2003). Our study was conducted in a Finnish, research-intensive university, which has the strategic objective that every teacher researches and every researcher teaches. According to the university's educational leadership and management strategy, the academic community conducts research-based activities concerning both teaching and learning, in addition to discipline-specific research.

In this study, we consider whether members of the academic community share a consistent conception of 
research-based teaching and learning. Many studies have shown that there is variation in how teaching ( $\AA$ kerlind, 2008; Entwistle \& Walker, 2000; Kember, 1997; Virtanen \& Lindblom-Ylänne, 2010) and research (Brew, 2006) are conceptualized amongst academics. Indeed, substantial variation has been shown in a small-scale, interview-based study on academics' experiences of the relationship between teaching and research (Robertson $\&$ Bond, 2011). Therefore, before any shift towards a closer integration and coherence of research and teaching, there is a need for further consideration of the conceptions of the research-teaching nexus, and clarification of the actual nature of the relationship between these two fundamental components of academic work.

Furthermore, we analyze the conceptions regarding research-based teaching and learning held by bioscience teachers and researchers, in an academic community with a close integration of research and teaching. We also examine how the combination of teaching and research is implemented in practice by teachers. We thereby attempt to determine whether the academic community shares a common conception of research-based teaching and learning, as a common vision is essential for creating common objectives for a an academic-community (Senge, 1994).

\subsection{Terminology Used in the Research-Teaching Nexus}

There are a number of terms that have been used to describe the research-teaching nexus. Griffiths (2004) described four categories: i) Research-led teaching is teaching structured around subject content with an emphasis on understanding research findings, rather than research processes, ii) Research-oriented teaching puts an emphasis on understanding the process of knowledge-generation, iii) research-informed teaching emphasizes the teaching and learning processes themselves and iv) Research-based teaching is largely designed around inquiry-based activities. In this case, the experiences of staff are highly integrated into student learning activities and the role distinctions between teacher and student are minimized, purposefully exploiting the interaction between research and teaching. Healey (2005) subsequently introduced the category research-tutored teaching, ('learning focused on students writing and discussing papers or essays'). There are also a number of additional related terms, such as research-enhanced teaching, teaching-enhanced research and research-aligned teaching that have been applied to the research-teaching nexus (Brew, 2006).

So far only Brew (2006) has studied what academics understand by the terms used in the research-teaching nexus. She conducted a multidisciplinary survey on what university teachers understand by research-led or research-enhanced teaching. She concluded that most academics viewed research-led teaching as 'learning through research' or 'presenting research to students'. A minority considered it as 'researching teaching' i.e. pedagogical research. There were clear interdisciplinary differences, and while a majority of teachers in education and the humanities considered research-led teaching as 'learning through research', the predominant view in science and technology was 'presenting research to students'. It should be noted that rather than asking directly about their conceptions of research-based teaching, the academics were asked to provide an example of it (Brew, 2006). Substantial variation has also been reported in studies of academics' experiences of the relationship between teaching and research. Robertson and Bond (2001), for instance, interviewed only seven academics, on the basis of which they distinguished five qualitatively different categories of experiences of the relationship between teaching and research.

\subsection{Research-Teaching Nexus}

The link between research and teaching can be perceived as specific or diffuse in form (Griffiths, 2004). In the specific relationship, research can be incorporated into bioscience teaching activities, typically in the form of field or laboratory courses. However, most of the time the link between the two is more diffuse, and the academic adopts a general orientation to the subject and tools for knowledge creation, i.e. provides experience on study design, information gathering, data analysis, publication and funding, into their teaching (Griffiths, 2004). This approach is close to higher education learning when viewed as students' perceiving characteristic ways of thinking and practising in the specific discipline (McCune \& Hounsell, 2005). Research can also be weakly embedded or strongly integrated into teaching activities (Griffiths, 2004). When weakly embedded, the research results might be mentioned in lectures or the preliminary reading for a course might consist of research articles. When research is strongly integrated into teaching, the students can, for example, prepare small research projects. The advantage of the shift of emphasis from weak to more strongly integrated research in teaching, is that the learning role of the students shifts from that of a passive learner towards a dialogue between the student and the teacher. In such an active dialogue between students and the teacher, the students can, for instance, give feedback on research ideas or research results (Griffiths, 2004).

In order to develope a closer link between research and teaching, Brew (2003) has called for the adoption of a new model based on scholarly knowledge-building communities (e.g. departments, whole universities and 
professional networks), in which the acquisition of knowledge is viewed as a process of construction. This new model is dynamic, focused on the process of knowledge construction and learning in a social context, involving all participants, irrespective of their role as students or academics. Linking research and teaching more closely does not necessarily imply that more students should be trained to perform academic research but that there should be closer links between research and teaching in academic communities, whereby both teaching and research are viewed as activities in which individuals and groups interact, constructing knowledge within a social context (Brew, 2003).

\subsection{The Nature of Teaching and Learning in Biosciences}

Each discipline has its own culture of thinking and practice, including both a research culture and a teaching culture, both being highly dependent on the discipline in question (Becher, 1994; Neumann, 2001; McCune \& Hounsell, 2005). Many major subjects in the biosciences have typically been viewed as hard pure fields of science (Biglan, 1973; Neumann, 2001; Neumann, Parry, \& Becher, 2002), in which research is typically perceived as basic research, carried out in large research groups, and from which the results are published as joint papers. However, some disciplines in the biosciences include applied fields, in which a lot of research is done in collaboration with non-academic institutions.

Some studies have shown that teaching in the natural sciences can consist of teacher-oriented sharing of basic knowledge, the main elements of which being inoculation of the subject content and teaching of research methods (Kreber \& Castleden, 2009; Lindblom-Ylänne, Trigwell, Nevgi, \& Ashwin, 2006; Lueddeke, 2003). This approach to teaching is likely to emanate from the perceived nature of knowledge in the field in question: fact-dominated pieces of information need to be taught before the coherent whole can be formed. However, there is an extensive history of teaching conducted via field and laboratory courses, which provide natural opportunities for the implementation of more student-orientated teaching methods.

\subsection{Research Questions}

The aims of this study are to determine whether bioscience teachers and researchers have consistent views on research-based teaching and learning, and the opinions of academics on how they conduct their work in the research-teaching nexus. By means of an open questionnaire, we studied 1) the conception of research-based teaching and learning of bioscience teachers and researchers, and 2) views on how research and teaching are combined in their everyday work.

\section{Methods}

\subsection{Participants}

This study was carried out at the Faculty of Biological and Environmental Sciences of the University of Helsinki, Finland. Being a research-intensive academic environment, the university strategy emphasizes that all teachers undertake research, and all researchers teach, and that students are considered to be members of the academic community. The faculty trains experts for careers in universities, research institutions, public administration, schools, business and industry.

The total number of academics in the Faculty was 220, of which 58 participated in this study. The participants included 10 professors, 18 assistant professors, 12 researchers, 10 doctoral candidates and 8 other academic staff, such as planners and research school coordinators. Of the participants, $52 \%$ were male and $48 \%$ female. The amount of teaching experience among the academics varied considerably: $51 \%$ had over 10 years, $12 \%$ had $6-10$ years, $9 \%$ had $3-5$ years, $26 \%$ had less than 2 years and one participant had no teaching experience. All the major subjects of the faculty but two, Genetics, and Environmental Change and Policy, were represented. These were Biochemistry, Biotechnology, Ecology and Evolutionary Biology, General Microbiology, Physiology, Plant Biology, Aquatic Sciences and Environmental Ecology.

\subsection{Data}

The data consisted of the questionnaire responses of 58 bioscience academics. The questionnaire comprised two open questions: Q1) In your opinion, what is research-based teaching and learning? and Q2) How are research and teaching combined in your own work? The questions were distributed via internal e-mail lists and the answers collected anonymously via an online electronic form. The drawback of this study method is the lack of possibility to ask elaborative questions. However, the respondents were provided with a space for additional comments, and unrelated answers were not included in the final analyses. Three and six responses respectively for Q1 and Q2 were rejected, because whilst they provided feedback on developing education in general, they did not answer our questions. 
The following background information was also collected: highest degree held (Degree), position at the university (Position), nature of contract with the university i.e. permanent/temporary staff (Employer), major subject (Major), age, gender, extent of research experience (Research) and duration of teaching experience (Teach). A space for additional comments was also provided.

\subsection{Analyses}

\subsubsection{Qualitative Content Analyses}

The data were analyzed using qualitative content analysis (Flick, 2002; Mayring, 2000). The basic idea of this method is that the elements of text interpretation, according to the research questions, are placed into categories, which are revised during the process of analysis. The method used is called inductive category development, in which the categories result from interpretation of the content of the responses, i.e. with no a priori categorization (Mayring, 2000). This method has similarities with phenomenograpy, in which the categories of description are considered to be the most important results of the research, and which aims to map the qualitatively different ways in which people conceive various aspects of their environment (Marton, 1981). Marton (1981) himself pointed out that the interview method is by no means an essential component of this method. The limitations with responses to anonymous questionnaires, as used in our study, include the impossibility to follow-up for clarification if the meanings of some responses remain unclear or incomplete. Thus, this could result in the recognition of an inadequate number of categories compared to phenomenographic analysis Marton (1981).

The material was analyzed step by step, according to the protocol of the procedure: 1) All responses were read independently by all three authors to identify the range of variation within the conceptions of research-based teaching and learning. 2) After the first reading, all authors listed comments under preliminary categories each had defined. 3) All the authors then discussed these and drafted a joint categorization. 4) After discussion, each author re-read the responses to redefine the categories. 5) The categories that each author identified were then discussed, modified and finalized. This process of re-reading and redefining continued until all the authors agreed on the categories. Finally, representative illustrative quotes from the teachers' responses were selected. This process was subsequently repeated for the teaching practices question. Finally the descriptions of teaching practices were evaluated and then compared to the range of conceptions. Some of the final categories had overlapping themes. However, the process of categorization does not use single themes as the determining factors but assesses the versatility of the themes, and maps the qualitatively different ways of determining the final categories.

\subsubsection{Quantitative Analyses}

Logistic regression was used for assessing the effects of eight explanatory variables collected as background information (Table A). The responses for Q1 were the seven dimensions found in the qualitative content analyses, and for Q2, the five defined categories. Logistic regression was performed on the categorized answers to each question in turn, using the statistical software R version 2.9.12.1 (R Development Core Team 2010) for the categorical responses to eight factors.

Prior to running the logistic regression model, the data were tested for autocorrelation. Autocorrelation was found between the factors Research and Degree, and Research and Position, so the term Research was removed from the model. The model was then run for each question separately using the remaining terms. Model optimization was performed by removing one term per run with the highest $\mathrm{p}$-value over $\mathrm{p}=0.5$, until a solution containing the remaining terms with values of $\mathrm{p}<0.5$ was achieved. Thus the final model for Q1 was: Research-based Teaching $\sim$ Degree + Position + Employer + Major + Gender + Teach , and the final model for Q2 was: Research Teach Meet $\sim$ Position + Major + Gender + Teach.

We also analysed the relationship between the categories of conceptions (Q1) and student involvement (Q2) produced in the qualitative content analyses. The relationship between the teachers' conceptions and degree of student involvement in their teaching were compared using Pearson's Chi-Square test, in the software package PASW Statistics 18, SPSS Inc. The test was performed using answers from the 48 respondents for which answers for both Q1 and Q2 were available. Irrelevant answers were omitted from the analyses. The variables for the test were the categories found in the qualitative content analyses.

\section{Results}

There was a lot of variation in how teachers described how they perceived research-based teaching and learning. Almost all teachers perceived that up-to-date knowledge and researchers acting in the role of teachers are characteristic of research-based teaching and learning. However, the teachers' conceptions varied from a very narrow perspective, by giving only one aspect to define the concept, to wider and more complex perspectives. 
Hence, our analysis showed not only qualitative differences in teachers' conceptions of research-based teaching and learning, but also quantitative differences in the number of dimensions described.

The most distinctive difference between the teachers was the way in which they perceived the students' role in the teaching and learning process, and the academic environment. Some teachers did not mention students at all, or if they did, students were mentioned simply as transient recipients of information from the teachers, whereas other teachers described students as active participants, almost junior colleagues, in the academic research community. This division was apparent in the analyses of both research questions.

The categorisation of the teachers' descriptions of research-based teaching is presented below in three parts. The first part addresses the teachers' conceptions of research-based teaching and learning, the second part their teaching practices, and the third part focuses on the relationship between conceptions and practices.

\subsection{Teachers' Conceptions of Research-Based Teaching and Learning}

We recognized seven different dimensions in the teachers' answers when they described research-based teaching and learning (Table 1). Each teacher's conception held one to several of these dimensions. For example, most teachers considered that a university teacher must also be a scientist, and there were also teachers for whom this was the only definition provided in their answers. Three additional distinctive categories emerged from our analysis (Table 1). Some teachers emphasized the role of the teacher when they described research-based teaching and learning, whereas the role of the student as an active participant in the learning process was not mentioned at all. The conceptions emphasising the teacher's role were grouped into one category, which was accordingly named the teacher-centred view. Some other teachers described not only the teacher's role but also recognized the role of student activity in the process of teaching and learning, which constituted the category student-centred view. A further minority of teachers emphasised the importance of pedagogical research in their responses, comprising the category pedagogical view.

There was a tendency that the number of dimensions increased when moving from the teacher-centred category to the categories student-centred and pedagogical views. However, in addition to this increase in the number of dimensions, there was also a discernible change in the quality of the answers. Teachers holding teacher-centred conceptions seemed to define their view from a narrower and more strictly limited perspective, whereas the other teachers' conceptions seemed to include more dimensions, to be more flexible, and to analyse the concept from more than one perspective. Hence, the three categories are exclusive along the teacher-centred/student-centred/pedagogy -axis but not hierarchical in terms of dimensions. Thus the conceptions categorized as a pedagogical view, may also include dimensions from the other two categories, in addition to which the conceptions categorized in the student-centred view may have dimensions from the category teacher-centred view.

Each teacher's conception was grouped in its entirety into just one category. Thus, the responses of 30 teachers fell into the category teacher-centred view, the responses of 24 teachers fell into the category student-centred view, and the responses of four teachers fell into the category pedagogical view. 
Table 1. Teachers' conceptions of research-based teaching and learning

\begin{tabular}{llll}
\hline Category & \multicolumn{1}{c}{ I } & \multicolumn{1}{c}{ II } & \multicolumn{1}{c}{ III } \\
\hline Core theme & Teacher-centred view & Student-centred view & $\begin{array}{l}\text { Research on } \\
\text { pedagogy viewed } \\
\text { important }\end{array}$ \\
$\begin{array}{l}\text { Teacher } \\
\text { Student }\end{array}$ & $\begin{array}{l}\text { Teachers role important } \\
\text { Student not mentioned }\end{array}$ & $\begin{array}{l}\text { Teacher not emphasized } \\
\text { Student as an active learner }\end{array}$ & $\begin{array}{l}\text { Student a passive } \\
\text { or active learner } \\
\text { or not mentioned }\end{array}$ \\
Dimensions & $\begin{array}{l}\text { Teacher an expert, teacher a } \\
\text { researcher }\end{array}$ & $\begin{array}{l}\text { Student learns by participating in } \\
\text { research }\end{array}$ & \\
& Up-to-date knowledge & $\begin{array}{l}\text { Students are producing research } \\
\text { results }\end{array}$ & \\
& $\begin{array}{l}\text { Scientific way of thinking and } \\
\text { practicing }\end{array}$ & Interaction, student provides & \\
& ideas to (teachers) research & \\
& & \\
& &
\end{tabular}

\section{Category 1. The Teacher-Centred View}

The teachers whose conceptions were categorised as teacher-centred view $(\mathrm{N}=30)$ held the opinion that research-based teaching and learning is determined by the teacher's activities. Within this category, if the teaching or learning process was referred to, it was viewed more or less as a transfer of knowledge from the teacher to the student. The responses from these teachers were often short and narrow, and included a unilateral definition of research-based teaching and learning. Within this category, the conceptions varied, depending on which of the dimensions the teacher emphasized. For example, one of the teachers considered that university teaching is research-based when the teachers are active researchers. Some other teachers considered that updating teaching material according to the most recent research findings will result in research-based teaching and learning. There were also teachers who considered that the process of researching should be taught to students. These teachers considered scientific thinking and discipline-specific research methods to be essential elements of research-based teaching. Thus, also these teachers did not consider students as active participants in the teaching and learning processes, but as recipients of information provided by the teacher, as the following excerpt demonstrates:

Research-based teaching is not presenting and showing research results. When you talk about research, you generally talk about the means and ways of gaining new knowledge, not about the ultimate truth. If you can get the student to see HOW, by which means and WAYS you can trust new knowledge and (at least temporarily) believe it, you have received one of the milestones of research-based teaching. (Teacher 13)

\section{Category 2. The Student-Centred View}

The characteristic feature of the conceptions of teachers within this category $(\mathrm{N}=24)$ was that the student was described as an active participant in the teaching-learning process. The teachers within this category, in common with teachers in the teacher-centred category, considered that a teacher must be an active researcher, and up-to-date knowledge in the discipline must be taught to the students. In addition, these teachers emphasized in various ways the students' own activity in the learning process. According to these teachers, students should learn the ways of practicing and thinking in the discipline by e.g. planning their own research projects, collecting data in the field or laboratory, analyzing it and reporting the results. Some teachers pointed out that students learn through completing assignments which resemble research projects, and one teacher appreciated students for providing new insights into research:

Research-based teaching means that the teaching given is based on up-to-date knowledge and that students also learn by participating in the work of the research groups, e.g. when making 
their theses and practical training. At its best (fortunately not uncommon) in interactive teaching, students provide new ideas to the research of their teachers. (Teacher 18)

\section{Category 3. Pedagogical Views}

The distinctive theme for this category was that the teachers $(\mathrm{N}=4)$ appreciated pedagogical research and awareness, as the following excerpt demonstrates:

Two different things. Research-based teaching actively follows new trends and results in research. The most recent information will be brought to students e.g. on advanced courses: the basics rarely change even if more research is being carried out. In theory, you could also perceive this as teaching based on research information on good teaching. Research-based learning therefore emphasizes the active role of students (this is in my opinion - this does not necessarily fit with any pedagogical theory, but this is how I would interpret it). For example, you give the students a "problem" for which they need to find possible solutions. It requires more from the teacher and the student but I think that the results are better than in the traditional teaching performing at the front. (Teacher 3 )

These teachers viewed teaching as a process which involves well-studied pedagogical methods, such as problem-based learning (PBL). Two of the teachers within this category also emphasized the importance and willingness to update and develop their teaching methods and skills.

Following the elucidation of these three categories, we assessed the importance of background variables in determining the categories. The logistic regression produced highly significant results for teaching experience, major subject, and gender $(\mathrm{p}<0.01)$, and a significant result also for contractual status at the university $(\mathrm{p}<0.05)$ (Table 2). There were more responses teacher-centred responses from permanent than from temporary staff. Teachers with 6-10 years of teaching experience were predominant in the teacher-centred category. All of the respondents in the group with 3-5 years teaching experience demonstrated perceptions which were categorized in the student-centred view of research-based learning.

Table 2. Logistic regression table for analysis of Q1 data for the six factors included in the model

\begin{tabular}{lccc}
\hline Factor & Chi-Square & d.f. & P \\
\hline Degree & 3.03 & 3 & 0.387 \\
Position & 2.66 & 3 & 0.447 \\
Employer & 8.35 & 2 & $0.015^{* *}$ \\
Major & 22.18 & 7 & $0.002^{* * *}$ \\
Gender & 11.68 & 1 & $0.001^{* * *}$ \\
Teaching experience & 16.11 & 5 & $0.007^{* * *}$ \\
TOTAL & 30.19 & 21 & 0.088 \\
\hline
\end{tabular}

Note. Significant probability values are indicated with asterisks, ${ }^{* * *}$ for $\mathrm{p}<0.01,{ }^{* *}$ for $\mathrm{p}<0.05$ and $*$ for $\mathrm{p}<0.1$.

\subsection{How are Research and Teaching Combined?}

The participants mentioned various teaching methods among the descriptions of how research and teaching are combined in their work. In their order of frequency, these were lecturing $(\mathrm{N}=36)$, supervising $(\mathrm{N}=19)$, teaching research methods $(\mathrm{N}=7)$, giving practical courses $(\mathrm{N}=16)$ and involving students directly in research activities $(\mathrm{N}=10)$. These groups of teaching methods are not exclusive, as participants reported various combinations of the different methods.

In general, when teachers' descriptions of the links between research and teaching were analysed, they formed a continuum. At one end of the continuum there were descriptions in which teaching and research did not meet at all, whereas at the other end of the continuum, the teachers' descriptions showed that research and teaching were strongly interlinked. The one factor which increased from one end of the continuum to the other was the extent of student involvement in teaching methods. Altogether our analysis resulted in five categories, with increasing levels of student involvement in research and participation in the research community (Table 3 ). 
Table 3. Student involvement in research, as viewed by the teachers

\begin{tabular}{|c|c|c|c|c|c|}
\hline Category & A & B & $\mathrm{C}$ & $\mathrm{D}$ & $\mathrm{E}$ \\
\hline $\begin{array}{l}\text { Core } \\
\text { theme }\end{array}$ & $\begin{array}{l}\text { Research and } \\
\text { teaching do } \\
\text { not meet }\end{array}$ & $\begin{array}{l}\text { Student connected } \\
\text { to research } \\
\text { through teacher }\end{array}$ & $\begin{array}{l}\text { Student practices } \\
\text { activities related to } \\
\text { research world }\end{array}$ & $\begin{array}{l}\text { Student } \\
\text { involved in } \\
\text { research }\end{array}$ & $\begin{array}{l}\text { Student involved as } \\
\text { part of the research } \\
\text { community }\end{array}$ \\
\hline Activity & - & $\begin{array}{l}\text { Lectures, } \\
\text { laboratory } \\
\text { courses, field } \\
\text { courses }\end{array}$ & $\begin{array}{l}\text { PBL, workshop } \\
\text { etc. }\end{array}$ & $\begin{array}{l}\text { Thesis } \\
\text { supervision/ } \\
\text { thesis work }\end{array}$ & $\begin{array}{l}\text { Carrying out } \\
\text { research }\end{array}$ \\
\hline Student & $\begin{array}{l}\text { No student } \\
\text { input in } \\
\text { research }\end{array}$ & $\begin{array}{l}\text { No student input } \\
\text { or input not } \\
\text { specified }\end{array}$ & Student active & $\begin{array}{l}\text { Student doing } \\
\text { thesis }\end{array}$ & $\begin{array}{l}\text { Student as part of } \\
\text { the research } \\
\text { community }\end{array}$ \\
\hline
\end{tabular}

\section{Category A. Teaching and Research are Mainly Separated}

In this category, the descriptions of the teachers $(\mathrm{N}=4)$ showed research and teaching as mainly separate entities. The teachers mostly considered that they carry out research, and teaching occupies a minor role in their work. One of the teachers described that his/her teaching in practice involves other topics besides his/her own research. It was characteristic for this category that teachers perceived that research and teaching do not meet, or the connection is minimal, as illustrated by the following excerpt:

I carry out research and only to a lesser extent teaching. There are some subjects in my teaching that deal with research, but mainly research and teaching do not meet in my work. (Teacher 36)

\section{Category B. Student Connected to Research through the Teacher}

Within this category, the teachers' $(\mathrm{N}=19)$ descriptions did show a connection between research and teaching, but the link was vague. Students were mentioned in the answers, but mainly as receptacles for the transfer of research-based information. Thus, some of the teachers in this category explained that they mention research results when lecturing. When these teachers described their teaching, the situations in the class were planned in advance and led by the teacher. Thus, the students were not perceived as active participants in the teaching situations, even if the teacher discussed a field or laboratory course. In this category it was characteristic that the student involvement in research was indirect, via the teacher:

When I can illustrate something I am teaching with research that I have done, or other peoples research that I am familiar with, I do it because (1) it makes it fun for me and (2) it makes the concept I am teaching more like a story than a fact to remember, so students (hopefully) get engaged in thinking about it. (Teacher 56)

\section{Category C. Student Practices - Activities Related to the Research World}

Teachers in this category $(\mathrm{N}=4)$ considered that teaching and research meet in their work when they carry out teaching practices, such as problem-based learning or workshops, in which students are active. However, the teachers do not refer to the students as active participants in the research or scientific community. One of the teachers refers to research results when lecturing, and tells the students how and why the results were produced, and in that way, tries to engage the students in critical thinking:

I teach mainly at the basic level, but even though the students are only starting their studies, I think you can bring research results related to the themes at hand into the teaching. This makes the basic teaching vivid and interesting, and hopefully will get students interested in their trade and commit themselves to further studies. With students who are more advanced in their studies, you can get into deep discussions on research aspects. For myself, linking research results to teaching brings variety and interest - it is rewarding to see how students can get excited about a research result, or how they understand the importance of critical thinking when you approach a research problem from different angles! (Teacher 46)

\section{Category D. Student Involved in Research - Supervision}

The teachers' descriptions in this group $(\mathrm{N}=18)$ stated that the students were involved in research by carrying out thesis work, either at the B.Sc., M.Sc. or Ph.D. levels. In most answers, the student was not mentioned as an active participant even in the supervision process, though in practice whilst doing their thesis, they are 
consequently involved in research. Some teachers within this category solely mentioned supervision, others combined supervision with activities and themes from other categories. However, they described supervision as the main connection between research and teaching, as the following excerpt shows:

Continuously when supervising M.Sc. - and Ph.D.-students. Also in advanced courses I regularly use the most recent research results. (Teacher 44)

\section{Category E. Student Integrated into the Research Community}

Within this group we categorized responses $(\mathrm{N}=6)$ in which the integration of research and teaching was emphasized and students were perceived as part of the research community. The responses seemed to comprise the idea that when combining teaching and research, the students provide input in producing novel research solutions, rather than just repeating research projects already carried out by the teacher, other scientists or students in former years. Many of these teachers also mentioned other teaching activities that have been emphasized in previous categories. However, the descriptions within this category differed from all the others in that the teachers described how they take advantage of different teaching situations to contribute to their own research. In these descriptions, the research and teaching activities seemed to be very strongly integrated, and the students were viewed as participants in the research community:

At my lectures I talk about material, which is from my field of research or even research done by my research group. Research shows, especially in laboratory courses, where I have carried out small-scale studies with undergraduate students, which we can later use as preliminary studies with postgraduate students. (Teacher 38)

Subsequent to the determination of these five categories, we assessed the significance of background variables in explaining these results. The results of the logistic regression produced a highly significant result $(p<0.01)$ for position, and a significant result for gender $(\mathrm{p}<0.05)$. High significance was also obtained for research experience and degree, which were autocorrelated with position. Therefore, position, research experience and degree seem to explain the majority of how research and teaching are combined in practice. Teachers that involve students in research tended to be researchers themselves, and generally referred to themselves as researchers.

Table 4. Logistic regression table for analysis of Q2 data for the four factors included in the model

\begin{tabular}{lccc}
\hline Factor & Chi-Square & d.f. & P \\
\hline Position & 12.84 & 3 & $0.005^{* * *}$ \\
Major & 7.84 & 7 & 0.347 \\
Gender & 3.19 & 1 & $0.074^{*}$ \\
Teaching experience & 8.70 & 5 & 0.122 \\
TOTAL & 21.44 & 16 & 0.162
\end{tabular}

Note. Significant probability values are indicated with asterisks, ${ }^{* *}$ for $\mathrm{p}<0.01,{ }^{* *}$ for $\mathrm{p}<0.05$ and $*$ for $\mathrm{p}<0.1$.

\subsection{Relationship between Teachers' Conceptions and Practices}

To compare academics' conceptions on research-based teaching and learning, and the practices demonstrating how research and teaching are combined in their own work, we used the categories defined in the qualitative content analysis (Tables 1,2$)$. Our analysis resulted in a statistically highly significant correlation $(\mathrm{p}<0.001)$, suggesting that teachers with teacher-centred conceptions of research-based teaching relied on practices in which students had minimal input. Contrastingly, teachers holding conceptions which represent the student-centred view, relied on practices which involve students in research and integrate them into the academic community.

\section{Discussion}

Our results show that bioscience teachers in a research-intensive university do not have common conceptions of research-based teaching. On the contrary, there is great variation in teachers' conceptions. Most teachers in our study perceived research-based teaching as the transfer of research results to students, with some emphasis on up-to-date information or scientific ways of thinking and practising. This teacher-centred view has similar elements to the view presenting research to students reported by Brew (2006) when studying academics' conceptions of research-led or research-enhanced teaching and learning. Contrastingly, the student-centred 
teachers in our study viewed students as active learners and did not emphasize the role of the teacher. Similarly, academics which held the view reported by Brew (2006) that learning through research required the engagement of students in research activities, and therefore had similar elements to those with a student-centred view in our study. Besides the division between teacher and student-centred conceptions, there were a minority of teachers in our study who viewed pedagogical research as important, or their conceptions showed pedagogical awareness and interest in developing and updating their teaching methods to enhance students' learning. This view has similar elements to the view researching teaching in the study of Brew (2006). By 'researching teaching' the academics referred to pedagogical research performed outside the teachers' own discipline.

Our results also share similarities with the results of a small interview study conducted by Robertson and Bond (2001), in which academics were interviewed on their experiences of teaching and research, and their inter-relationships. By interviewing seven academics, Robertson and Bond (2001) found five qualitatively different experiences of the relationship between research and teaching, ranging from research and teaching being incompatible and with no connection, to a symbiotic relationship in a learning community between the two This surprisingly great variety of experiences detected in a sample of just seven academics, may be explained by the study method. Academics expressing strong views on a paper suggesting little or no relationship between research and teaching (Hattie \& Marsh, 1996) were invited to join the study by Robertson and Bond (2001). Besides their views on the controversial paper, the academics were also interviewed on their personal experiences of the relationship between teaching and research. An interview-based on such a controversial topic is likely to provide extreme disparity in views and experiences.

The conceptions of research-based teaching revealed in this study are also in agreement with how academics are reported to view teaching in general in studies on approaches to teaching. Approaches to teaching are defined as strategies adopted by teachers for their teaching, and conceptions as the beliefs that underlie their teaching strategies (Postareff \& Lindblom-Ylänne, 2008). Two approaches to teaching have been commonly distinguished: the teacher-centred approach and the student-centred approach (Kember \& Kwan, 2000; Postareff \& Lindblom-Ylänne, 2008; Trigwell \& Prosser, 1996). In the teacher-centred approach, the student is viewed as a passive recipient of information transmitted from the teacher to the student. This way of perceiving students is similar to the ways teachers perceived students in our teacher-centred view, in which the students were considered as recipients of information or not mentioned at all. Contrastingly, in the student-centred approach, the teaching is seen to constitute a facilitator of the students' learning processes, which is similar to our student-centred view, in which the teachers in this category perceived students as active participants in the learning process, and described their conceptions by referring to students' learning.

It has been shown that teaching and learning processes are interlinked. Teacher/knowledge-centred and student-centred approaches were reported in a study of bioscience students' conceptions of teaching (Virtanen \& Lindblom-Ylänne, 2010). Furthermore, Trigwell, Prosser, Ramsden and Martin (1998) have shown that different approaches to teaching influence students' approaches to learning, meaning that teachers with a teacher-centred approach to teaching are more likely to be favoured by students with a superficial approach to learning, and teachers with a student-centred approach to teaching are likely to be favoured by students with a deep approach to learning. Consequently, teachers' conceptions of teaching in general, and of research-based teaching in particular, are likely to have an effect on students' learning.

As suggested by Hattie and Marsh (1996) and Brew (2003, 2006), a closer integration of teaching and research is required to enhance higher education. Our study demonstrates that bioscience academics in a research-intensive university refer to the role of the student in a variety of different ways and possess a diverse range of conceptions of research-based teaching. In our opinion, the creation of a common conception of research-based teaching is essential in order to foster a stronger integration of research into teaching. This approach could be considered as the creation of a community of practice, defined by Lave and Wenger (1991, p. 98) as "a set of relations among persons, activity and world, over time and in relation with other tangential and overlapping communities of practice". In the model of Brew (2003), there are no separate learning and research environments at the university, but the student is involved as an active member of the research community. In practice, the attainment of such an interactive research-teaching community is gradually accomplished when proceeding towards student-focused conceptions and teaching practices.

There is a plethora of ways of involving students in research (Table 2). As suggested by Zarmorski (2000) students can be seen as an audience for research results or they can be engaged in research activity. This division is not entirely equivalent to the teacher-centred and student-centred approaches (Kember \& Kwan, 2000; Postareff \& Lindblom-Ylänne, 2008; Trigwell \& Prosser, 1996), and engaging students in research activities does not automatically constitute a student-centred approach. This is illustrated by our results on student 
involvement, in which a common way for bioscience academics to involve students in practical research activities related to the research world is via field or laboratory courses. However, participation in a field or laboratory course does not necessarily mean student-centred learning. The course exercises are often designed in advance by the teacher, and applied in a teacher-centred approach, in which the student may mechanically carry them out without the necessity of further thinking or deep learning. This may be the case amongst bioscience academics in particular, as many teachers described giving lectures, laboratory and field courses, in a teacher-oriented manner, without considering the role of the student in these activities. Such an approach can be referred to as activity-based teacher-focused teaching (McKenzie, 2004).

Our results suggest that academics' conceptions of research-based teaching correlate with teaching practices with various levels of student involvement in research. This means that teachers with teacher-centred views of research-based teaching are likely to carry out teaching practices with less student involvement, and teachers' with student-centred views are more likely to incorporate students into research activities and acquaint them with the academic community. Supervision of theses was commonly perceived as constituting a research-based teaching activity, however only a minority of bioscience teachers carried out teaching practices whereby students could be considered to participate in the academic community. This may have significant effects on students' study engagement, as Stubb, Pyhältö, and Lonka (2011) have shown that doctoral students who feel that they are part of the scholarly community, are inspired and empowered, and more likely to succeed in their studies, compared to students who do not feel part of a scholarly community.

Our study also produced some interesting results regarding the associations between teachers' conceptions and background variables. For example, major subject had a significant effect on teachers' conceptions. We suspect that this could be because of effective educational leadership within some major subjects, or that teaching staff in some majors are actively developing their pedagogical skills and influencing their peers, whereas those in other majors are not. Interestingly, there were more teacher-centred responses from permanent staff than from temporary, and teachers with 6-10 years of teaching were overwhelmingly dominated by the teacher-centred approach. Contrastingly, all of the respondents in the group with 3-5 years teaching experience demonstrated student-centred perceptions of research-based learning. This suggests that teachers in the early stages of their career (i.e. teachers without permanent teaching positions) may have more incentive for training and developing their pedagogical skills than permanent staff. The same trend was shown in views of practical teaching solutions, as the most significant factor affecting teaching practices was position at the university: the majority of teachers who involved students in research were researchers. This result suggests that active researchers are a valuable resource for the development and application of research-based learning, and it also supports the wisdom of the university's strategic objective of implementing a policy of 'all teachers undertake research, and all researchers teach'.

\section{Conclusion}

In conclusion, we consider that if the conception of research-based teaching is not developed collectively, it will not evolve by itself amongst academics. The active development and refinement of joint conceptions of research and teaching is vital in a research-intensive institution, as they have the potential to enhance student involvement in research and incorporation into the academic community. This in turn can enhance student achievement, and thereby enhance higher education. Such progress towards the establishment of a genuinely research-based teaching community with common conceptions will require both pedagogical training of academics and the implementation of effective educational management and leadership at the departmental, major subject and institutional levels

\section{Acknowledgements}

We thank Anne Nevgi for helpful comments on the manuscript and Jyrki Lappalainen for helping with the statistics.

\section{References}

Åkerlind, G. (2008). An academic perspective on research and being a researcher: an integration of the literature. Studies in Higher Education, 33, 17-31. http://dx.doi.org/10.1080/03075070701794775

Barnett, R. (1997). Higher Education: A critical business. Buckingham, UK: Open University Press.

Becher, T. (1994). The significance of disciplinary differences. Studies in Higher Education 19, 151-161. http://dx.doi.org/10.1080/03075079412331382007

Biglan, A. (1973). The characteristics of subject matter in different academic areas. Journal of Applied Psychology, 57, 195-203. http://dx.doi.org/10.1037/h0034701 
Brew, A. (2003). Teaching and Research: New relationships and their implications for inquiry-based teaching and learning in higher education. Higher Education Research \& Development, 22, 1-18. http://dx.doi.org/10.1080/0729436032000056571

Brew, A. (2006). Research and Teaching-Beyond the Divide. Houndmills, Basingstoke, UK: Palgrave Macmillan.

Entwistle, N., \& Walker, P. (2000). Strategic alertness and expanded awareness within sophisticated conceptions of teaching. Instructional Science 28, 335-361. http://dx.doi.org/10.1007/978-94-010-0593-7_2

Flick, U. (2002). An introduction to qualitative research (2nd ed.). London, UK: Sage.

Griffiths, R. (2004). Knowledge production and the research-teaching nexus: the case of the built environment disciplines. Studies in Higher Education 29, 709-726. http://dx.doi.org/10.1080/0307507042000287212

Hattie, J., \& Marsh, H. W. (1996). The relationship between research and teaching-a meta-analysis. Review of Educational Research 66, 507-542. http://dx.doi.org/10.3102/00346543066004507

Healey, M. (2005). Linking research and teaching: exploring disciplinary spaces and the role of inquiry-based learning. In R. Barnett (Ed.), Reshaping the University: New Relationships between Research, Scholarship and Teaching (pp. 67-78). McGraw Hill: Open University Press.

Kember, D. (1997). A reconceptualisation of the research into university academics' conceptions of teaching. Learning and Instruction 7, 255-275. http://dx.doi.org/10.1016/S0959-4752(96)00028-X

Kember, D., \& Kwan, K.-P. (2000). Lecturers' approaches to teaching and their relationship to conceptions of good teaching. Instructional Science 28, 469-490.

Kreber, K., \& Castleden, H. (2009). Reflection on teaching and epistemological structure: reflective and critically reflective processes in 'pure/soft' and 'pure/hard' fields. Higher Education 57, 509-531.

Lave, J., \& Wenger, E. (1991). Situated learning: Legitimate peripheral participation. Cambridge: Cambridge University Press.

Lindblom-Ylänne, S., Trigwell, K., Nevgi, A., \& Ashwin, P. (2006). How approaches to teaching are affected by discipline and teaching context. Studies in Higher Education, 31, 285-298. http://dx.doi.org/10.1023/A:1026569608656

Lueddeke, G. R. (2003). Professionalising teaching practice in higher education: a study of disciplinary variation and "teaching-scholarship". Studies in Higher Education, 28, 213-228. http://dx.doi.org/10.1080/0307507032000058082

Marton, F. (1981). Phenomenography: Describing conceptions of the world around us. Instructional Science 10, 177-200. http://dx.doi.org/10.1007/BF00132516

Mayring, P. (2000). Qualitative Content Analysis. Forum: Qualitative Social Research, 1(2), Art.20.

McCune, V., \& Hounsell, D. (2005). The development of students' ways of thinking and practising in three final-year biology courses. Higher Education, 49, 255-289. http://dx.doi.org/10.1007/s10734-004-6666-0

McKenzie, J. (2004). Critical aspects and dimensions of variation: Extending understandings of ways of experiencing teaching. Paper presented at the meeting Improving Student learning International Symposium, Oxford Centre for Staff and Learning Development, Oxford Brookes University.

Neumann, R. (2001). Disciplinary differences and university teaching. Studies in Higher Education 26, 135-146. http://dx.doi.org/10.1080/03075070120052071

Neumann R., Parry, S., \& Becher, T. (2002).Teaching and learning in their disciplinary contexts: a conceptual analysis. Studies in Higher Education 27, 405-417. http://dx.doi.org/10.1080/0307507022000011525

Postareff, L., \& Lindblom-Ylänne, S. (2008). Variation in teachers' descriptions of teaching: Broadening the understanding of teaching in higher education. Learning and Instruction, 18, 109-120. http://dx.doi.org/10.1016/j.learninstruc.2007.01.008

Robertson J., \& Bond, D. (2001). Experiences of the relation between teaching and research: what do academics value? Higher Education Research and Development, 20, 5-19. http://dx.doi.org/10.1080/07924360120043612

Senge P. M. (1994). The Fifth Discipline. The Art \& Practice of the Learning Organization. New York, NY: Currency Doubleday. 
Shore, B., Pinker, S., \& Bates, M. (1990). Research as a model for university teaching. Higher Education, 19, 21-35. http://dx.doi.org/10.1007/BF00142021

Stubb J., Pyhältö, K., \& Lonka, K. (2011). Balancing between inspiration and exhaustion: PhD students' experienced socio-psychological well-being. Studies in Continuing Education 33, 33-50. http://dx.doi.org/10.1080/0158037X.2010.515572

Trigwell, K., \& Prosser, M. (1996). Changing approaches to teaching: A relational perspective. Studies in Higher Education, 21, 275-284. http://dx.doi.org/10.1080/03075079612331381211

Trigwell, K., Prosser, M., Ramsden, P., \& Martin, E. (1998). Improving student learning through a focus on the teaching context. In G. Gibbs (Ed.), Improving student Learning (pp. 97-103). Oxford: Oxford Centre for Staff Development.

Virtanen V., \& Lindblom-Ylänne, S. (2010). University students' and teachers' conceptions of teaching and learning in the biosciences. Instructional Scienc, 38, 355-370. http://dx.doi.org/10.1007/s11251-008-9088-z

Zamorski, B. (2000). Research-led teaching and learning in higher education. Norwich: Centre for Applied Research in Education, University of East Anglia.

\section{Appendix}

\section{Variables Collected as Background Information}

Table A. Eight factors surveyed in the questionnaires to provide explanatory variables for use in the analyses

\begin{tabular}{|c|c|c|c|c|c|c|c|c|c|c|c|}
\hline Factor & Respon & e catego & & & & & & & & & \\
\hline Degree & M.Sc. & $\begin{array}{l}\text { Ph. } \\
\text { Lic. }\end{array}$ & Ph.D. & Docent & & & & & & & \\
\hline Position & $\begin{array}{l}\text { Post } \\
\text { grad. }\end{array}$ & $\begin{array}{l}\text { Resea } \\
\text { rcher }\end{array}$ & $\begin{array}{l}\text { Lectu } \\
\text { rer }\end{array}$ & Prof. & $\begin{array}{l}\text { Oth } \\
\text { er }\end{array}$ & & & & & & \\
\hline Contract & $\begin{array}{l}\text { UH } \\
\text { perm. }\end{array}$ & $\begin{array}{l}\text { UH } \\
\text { temp. }\end{array}$ & $\begin{array}{l}\text { Exter } \\
\text { nal }\end{array}$ & $\begin{array}{l}\text { Non-tea } \\
\text { ching, } \\
\text { non-rese } \\
\text { arch }\end{array}$ & & & & & & & \\
\hline $\begin{array}{l}\text { Major } \\
\text { subject }\end{array}$ & $\begin{array}{l}\text { Aquat } \\
\text { ic }\end{array}$ & $\begin{array}{l}\text { Bioch } \\
\text { emistr } \\
\text { y }\end{array}$ & $\begin{array}{l}\text { Biote } \\
\text { chnol } \\
\text { ogy }\end{array}$ & Eco-Evo & $\begin{array}{l}\text { Phy } \\
\text { siol } \\
\text { ogy }\end{array}$ & $\begin{array}{l}\text { Plant } \\
\text { biolo } \\
\text { gy }\end{array}$ & $\begin{array}{l}\text { Genet } \\
\text { ics }\end{array}$ & $\begin{array}{l}\text { Micro } \\
\text { biolog } \\
\text { y }\end{array}$ & $\begin{array}{l}\text { Env. } \\
\text { Ecol. }\end{array}$ & $\begin{array}{l}\text { YMP } \\
\text { S }\end{array}$ & Other \\
\hline Age & $<30$ & $31-40$ & $41-50$ & $51-60$ & $>61$ & & & & & & \\
\hline Gender & M & $\mathrm{F}$ & & & & & & & & & \\
\hline Research & $\begin{array}{l}\text { PG } \\
\text { inexp } \\
\text { erienc } \\
\text { ed }\end{array}$ & $\begin{array}{l}\text { PG } \\
\text { experi } \\
\text { enced }\end{array}$ & $\begin{array}{l}\text { Post } \\
\text { doc }\end{array}$ & Senior & $\begin{array}{l}\text { Inte } \\
\text { rnat } \\
\text { iona } \\
1\end{array}$ & & & & & & \\
\hline Teaching & None & Little & $\begin{array}{l}1-2 \\
\text { years }\end{array}$ & $\begin{array}{l}3-5 \\
\text { years }\end{array}$ & $\begin{array}{l}6-1 \\
0 \\
\text { year } \\
\text { s }\end{array}$ & $\begin{array}{l}>10 \\
\text { years }\end{array}$ & & & & & \\
\hline
\end{tabular}

Note. The factors were the highest degree held, position at the university, nature of contract with the university, major subject, age, gender, extent of research experience and duration of teaching experience. $\mathrm{UH}=$ University of Helsinki, Eco-Evo = Ecological and Evolutionary Biology, Env. Ecol. = Environmental Ecology, YMPS = Environmental Change and Policy, $\mathrm{M}=$ Male, $\mathrm{F}=$ Female, $\mathrm{PG}=$ Post Graduate 


\section{Copyrights}

Copyright for this article is retained by the author(s), with first publication rights granted to the journal.

This is an open-access article distributed under the terms and conditions of the Creative Commons Attribution license (http://creativecommons.org/licenses/by/3.0/). 